\title{
Energy, economical and ecological analysis of a single-family house using photovoltaic installation
}

\author{
Ewelina Krawczak ${ }^{1, *}$ \\ ${ }^{1}$ Institute of Renewable Energy Engineering, Faculty of Environmental Engineering, Lublin \\ University of Technology, Nadbystrzycka 40B, 20-618 Lublin, Poland
}

\begin{abstract}
According to European Union politics, Poland is expected to achieve at least $15 \%$ of the final energy consumption from renewable sources and to reduce $20 \%$ of greenhouse gases reduction in comparison to 1990. Among a variety of sources, (i.e. wind, biomass, geothermal, solar) energy conversion is one of the most promising solutions. The solar energy is clean and free. PV installations do not produce $\mathrm{CO}_{2}$ gas to the atmosphere and can be installed to any size based on individual energy demands. Besides, the investment costs for such systems drops every year. Above mentioned reasons cause a strong interest in small photovoltaic installations, and an increasing number of energy prosumers. Selling electricity to the grid in the present renewable energy legislation is not profitable. For this reason energy produced from PV installations should be consumed directly where is produced. This paper shows the results of the computer simulations and analysis of annual, winter and summer half year energy yield of photovoltaic system for a single-family house. Following orientations were taken into account: east-west, south. Effect of tilt angle of the modules integrated with building façade was investigated. Economic and ecological aspects were analysed. DDS-Cad and PVSyst software were used for modelling and simulations.
\end{abstract}

\section{Introduction}

According to Directive 2009/28/EC of the European Parliament and of the Council of 23 April 2009 on the promotion of the use of energy from renewable sources, Poland should achieve at least $15 \%$ of the final energy consumption from renewable sources and $20 \%$ of greenhouse gases reduction compared to the 1990 , by the year 2020 . A long-term development strategy as well as a sustainable energy policy that supports individual energy consumers are strongly needed. One of the example solution considered in Poland in The National Renewable Energy Action Plan is to support the development of distributed renewable energy sources, such as small photovoltaic (PV) household installations. The 'Prosument' system is one of the propositions for individual energy producers. Usage of renewable energy sources leads to improve energy efficiency and reduces emission of greenhouse gases, e.g. $\mathrm{CO}_{2}, \mathrm{NO}_{\mathrm{x}}$, to the atmosphere. What is more, society is looking for

\footnotetext{
${ }^{1}$ Corresponding author: e.krawczak@pollub.pl
} 
alternatives to fossil fuels, whose resources are going to be exhausted and thus more expensive in the nearest future. For this reason the prices of conventional energy production (i.e. coal based) become also high and they will grow in the future, in a long-term perspective. Conventional fuels can be replaced by solar energy, which is free and environmentally friendly [1]. Solar energy might be partly a solution for the energy crisis and environmental problems [2]. According to Polish Energy Regulatory Office, in the end of 2017, the total installed PV capacity connected to the electricity grid was about $108 \mathrm{MW}$. Additionally, the amount of electricity generated in photovoltaic power plants confirmed by green certificates was $58.5 \mathrm{MWh}$. The above mentioned factors are the most significant reasons to develop the renewable energy sources market and increase interest in photovoltaic systems [3].

The orientation as well as the tilt of photovoltaic modules should be chosen correctly in order to maximize the energy yield, especially for non-tracking installations [4-6]. The factor determining the efficiency of PV modules in not only their orientations but also their type. Nowadays, the most widely applied technology is based on silicon material, which has a dominant role in the PV market. Monocrystalline modules reach an efficiency of up to $26.7 \%$, while the polycrystalline up to $21.9 \%$. However, solar cells based on thin film are strongly investigated as well. Amorphous silicon is $2^{\text {nd }}$ generation solar cells material with cell efficiencies of $10.2 \%$ [7]. What is more, the solar cells based on copperindium-gallium-diselenide (CIGS) materials can be a valuable substitute to Si crystalline technology since their recent highest noticed efficiency of the lab solar cells equals $22.4 \%$ and is close to the efficiencies of the silicon devices [8-9]. Thin-films technologies are constantly improved, even though application transparent electrodes based on non-toxic, abundant material with good electrical and optical properties, such as zinc oxide $(\mathrm{ZnO})$ or zinc oxides doped with III group elements - Al, Ga, B, In [10].

Exemplary situation of positioning solar system is when sun rays reach the PV module perpendicularly in order to optimise solar insolation on PV array's surface. Annual energy output of PV system depends on many external factors including sun's path which varies with the day number, cloud coverage [11], wind [12], temperature [13], shading and dust, as well as with the location [14-15]. The tilt is related to the seasons, whilst azimuth angle to days. An optimal solution could be the PV installation on a dual-axis tracker that follows the sun constantly, changeable with time [16]. However such systems have many limitations, for example cannot be installed on the roofs. What is more, they need empty space in the vicinity of the household. For this reason an optimal configuration of the PV system on the roof is needed.

Due to significant dependence of the output energy on geographical location (latitude), time of a day or year, as well as on meteorological conditions, the change in the orientation of a photovoltaic module requires individual approach. Various models were proposed for optimizing the tilt angle and orientation of solar modules designed for different geographical latitudes [17-20]. However, optimal orientation of solar installation leads to achieve maximum annual energy yield, which cannot optimize the others indicators, such as direct self-consumption of energy produced. Taking into account existing Polish legislation ('Prosument') it might be more important to increase self-consumption instead of maximizing the total energy output.

This paper presents the computational analysis including determination of optimum azimuth for photovoltaic installation located in Warsaw, Poland, in order to maximize the energy self-consumption of the household. The simulations were carried out on the basis of seasonal energy demand patterns. Influence of orientation on the total energy output of PV arrays, as well as direct consumption was found. Dependency of the energy supplied to the user on economic aspects of 'Prosument' subsidy was also examined. The ecological aspect in terms of greenhouse gases emission reduction was also investigated. 


\section{Methodology}

A computational analysis with the use of DDS-Cad and PVSyst software was carried out for single-family house placed in Warsaw, the capital of Poland, in order to simulate energy yield and obtain useful data about self-consumption. The photovoltaic (PV) system was analysed under polish climate conditions with different azimuth orientations. Solar module azimuth was varied from $-60^{\circ}$ to $60^{\circ}$ with the step of $15^{\circ}$, which resulted in 9 different orientations. In each case, the size and components of the system, and thus all indicators were kept constant. 3D model of the building was prepared in the DDS-Cad software by considering buildings' characteristics and geometry of the rooftop. The load consumption estimations were based on seasonal energy profiles. The simulations of energy yield as well as energy self-consumption were carried out.

\subsection{Site information}

The geographical site selected for the case study is the capital of Poland - Warsaw - located at $52^{\circ} 27^{\prime} \mathrm{N} 20^{\circ} 98^{\prime} \mathrm{E}$ and $96 \mathrm{~m}$ above sea level with annual air temperature equals $9^{\circ} \mathrm{C}$. The residential object has 2 storeys of $2.8 \mathrm{~m}$ high. The usable area is $180 \mathrm{~m}^{2}$ and the volume is $504 \mathrm{~m}^{3}$. The dwelling is designed to be inhabited full time by a three person family: working parents with a child. The roof of the building is made of 4 parts. The roof slope is $35^{\circ}$. Meteorological data obtained from the Metenorm 7.1 were implemented for the irradiation calculation (Table 1). Based on the Koeppen-Geiger classification Poland has two climate zones. Cfb Climate (warm, humid climate) exists in the southern parts and Dfb Climate (humid, snow climate) in the mountainous regions. Additionally, according to the Polish classification, Warsaw is located in the third group characterized by average values of outside and annual temperature equal to $-20^{\circ} \mathrm{C}$ and $7.6^{\circ} \mathrm{C}$ respectively.

Table 1. Meteorological data of selected location (Warsaw, Poland).

\begin{tabular}{|c|c|c|c|c|c|c|c|c|c|c|c|c|}
\hline & Jan & Feb & Mar & Apr & May & Jun & Jul & Aug & Sep & Oct & Nov & Dec \\
\hline $\begin{array}{c}\text { Global irradiation } \\
{\left[\mathbf{k W h} / \mathbf{m}^{2}\right]}\end{array}$ & 20.2 & 34 & 75.8 & 116.7 & 162.3 & 167.1 & 169 & 142.3 & 91.6 & 53 & 22 & 14.3 \\
\hline $\begin{array}{c}\text { Diffuse irradiation } \\
{\left[\mathbf{k W h} / \mathbf{m}^{2}\right]}\end{array}$ & 14.84 & 23.56 & 46.71 & 61.26 & 62.87 & 82.78 & 81.11 & 73.64 & 51.11 & 28.01 & 16.09 & 10.39 \\
\hline
\end{tabular}

\subsection{Photovoltaic system description}

A small grid-connected residential system without battery back-up was analysed. PV installation consists of 14 polycrystalline silicon solar modules of $208 \mathrm{Wp}$ each from Sharp USA manufacturer (ND-208 U1 model). Total installed power capacity is $2.9 \mathrm{kWp}$. Overall area covered by modules is $22.8 \mathrm{~m}^{2}$. They are positioned in mounting system at a fixed tilt equal to the roof slope of $35^{\circ}$. PV modules are formed into string and are connected to a $2.5 \mathrm{~kW}$ Kaco New Energy inverter of Powador 3002 model. The chosen site of the installation is free from shadowing.

\subsection{Load consumption in residential building}

Electricity demand of analysed family residential house was considered as low. Main electrical devices from the following groups: lighting, cooking equipment, heating, and other appliances were taken into account to estimate energy consumption. Furthermore seasonal modulation profiles were adopted (Fig. 1). The average daily demand for electricity of the analysed house was calculated to be $6.5 \mathrm{kWh} / \mathrm{d}$. 

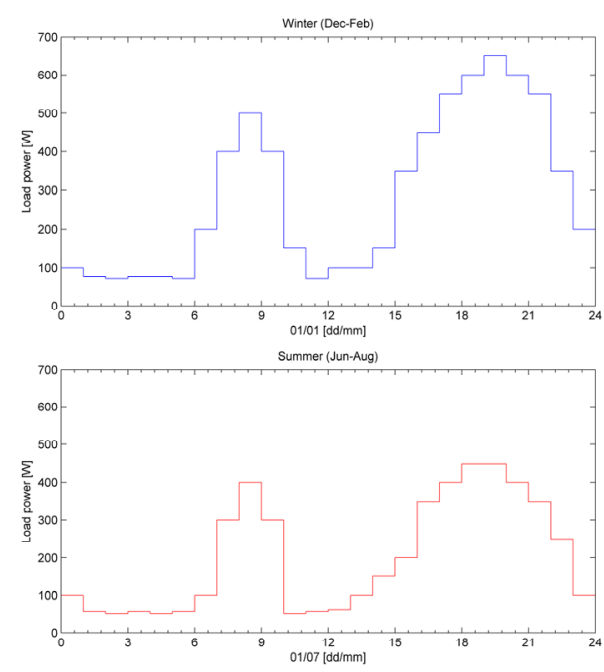
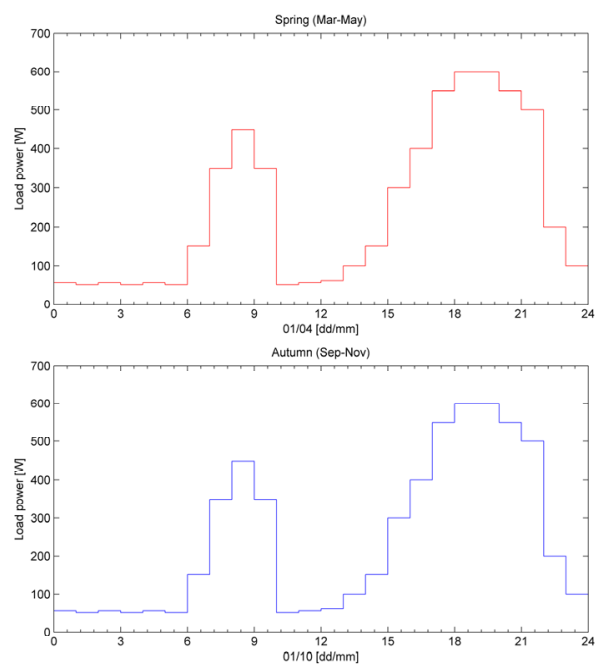

Fig. 1. Season modulation of energy consumption daily profiles.

\section{4 'Prosument' system in Poland}

'Prosument' system has been proposed by Polish Government in 2016 to increase the interest of energy consumers in photovoltaics and other renewable energy systems. According to this idea, 'Prosumer' should be interpreted as a producer and an energy consumer at the same time. The settlement usually takes place in an annual period time. However, only $70 \%$ or $80 \%$, in dependence of installation size, can be retaken from the grid in an annual period time. For this reason, it seems to be more profitable to increase the energy self-consumption produced by PV system.

\section{Results and discussion}

\subsection{Energy analysis}

Figure 2 shows the results of the computational analysis of annual energy yield in function of solar azimuth. The orientation of the PV arrays was changed from $-60^{\circ}$ on the East to $60^{\circ}$ on the West with the step of $15^{\circ}$. The quantity and type of solar modules as well as other components were kept fixed in each case. The tilt was equal to $35^{\circ}$.

The maximum energy production was obtained for the azimuth equals $0^{\circ}$. The amount of energy obtained was $2972 \mathrm{kWh} / \mathrm{y}$. It can be assumed that $1 \mathrm{kWp}$ od PV installation can produce $1021 \mathrm{kWh}$ yearly. Horizontal global irradiation was equal to $1068.2 \mathrm{kWh} / \mathrm{m}^{2}$. The $15^{\circ}$ deviation to the East as well as to the West resulted in decreasing of energy yield to $2957 \mathrm{kWh} / \mathrm{y}$, which is about $2 \%$ less than yield for azimuth $0^{\circ}$. Normalized production was noticed as $1015 \mathrm{kWh} / \mathrm{kWp} / \mathrm{y}$. Further increasing of the azimuth caused decreasing of the energy production to $931 \mathrm{kWh} / \mathrm{kWp} / \mathrm{y}\left(\right.$ for $60^{\circ}$ ). It can be seen that orientation shift by $60^{\circ}$ gave rise to discernible difference in the amount of energy produced which equals $10 \%$ in respect of optimal orientation angle. The production decreased from $2972 \mathrm{kWh} / \mathrm{y}$ to $2703 \mathrm{kWh} / \mathrm{y}$. 


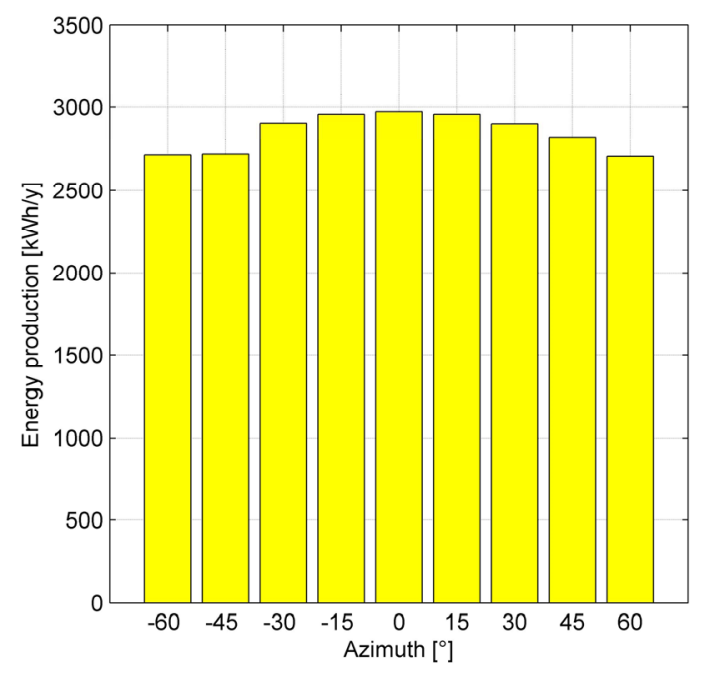

Fig. 2. The energy production dependency on solar azimuth.

From the economical point of view, a very important indicator is the amount of energy which can be directly consumed. Figure 3 compares the energy supplied to the user at defined orientations. Self-consumption profiles were carried out on the basis of season modulation of daily profiles, described in the section 2.3. Average daily demand was determined as $6.5 \mathrm{kWh} /$ day. Direct consumption of generated PV power do not show the same dependence as energy production for solar azimuth. The highest energy usage was noticed for solar azimuth of $30^{\circ}$ to the west. It can be used $650 \mathrm{kWh} / \mathrm{y}$ energy directly. The orientation's shift to the east resulted in a decreasing of self-consumption, towards to the west lead-to an increase. However, further increasing of the solar azimuth to the west leads to a decrease of self-consumption as well.

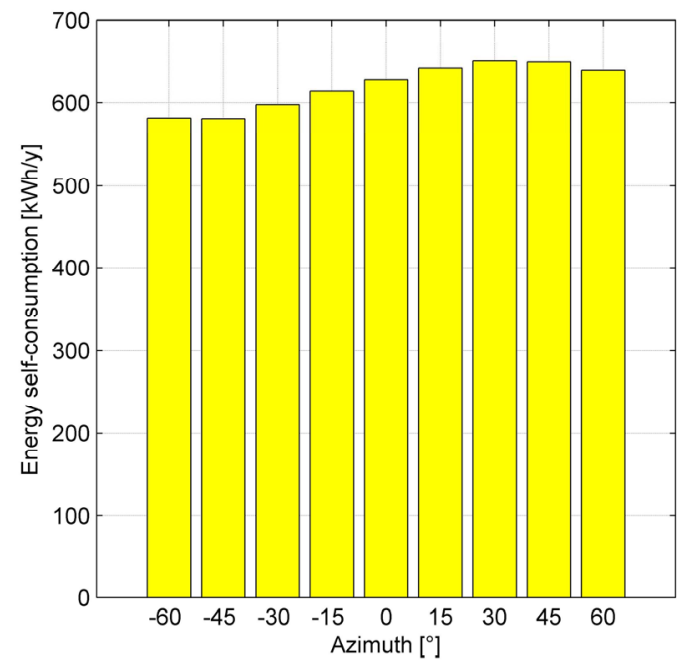

Fig. 3. The energy self-consumption dependency on solar azimuth. 
For further optimization of the orientation of the PV array the amount of energy injected to the grid, excluding self-consumption, has been considered. Taking into account the total energy production and energy supplied to the user, it can be seen from Figure 4 that the highest values of energy injected into the grid are for the orientations ranged between $-15^{\circ}$ and $15^{\circ}$. For those orientations, the output power was also the highest (compared to Fig. 2). It can be assumed that $80 \%$ of energy produced is unused by the household directly. The finest energy usage to the total energy production ratio is for orientation equals $60^{\circ}$, which is up to $25 \%$.

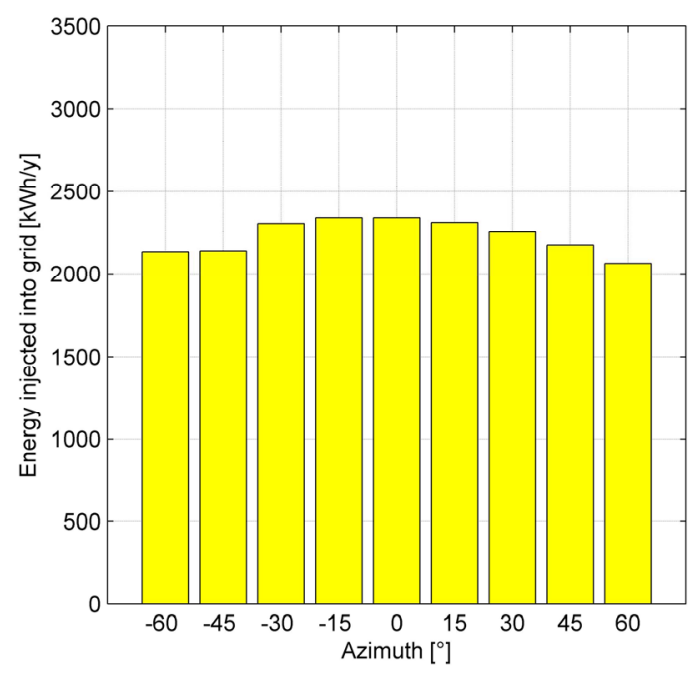

Fig. 4. The energy injected into grid dependency on solar azimuth.

\subsection{Economical analysis}

The cost-reimbursement time analysis was carried out on the basis of the 'Prosument' system. The main establishment of the subsidy is the possibility of retaken from $70 \%$ to $80 \%$ of the energy injected to the grid beforehand. To calculate payback period, the following assumptions were made: the capacity of the PV installation $-2.9 \mathrm{kWp}$, cost of installation $1190 € / \mathrm{kWp}$, energy entity cost in Poland $-0.14 € / \mathrm{kWh}$. An increase of the energy prices as well as decrease of the efficiency of the modules were not taken into account.

It can be seen from the Table 2 that amount of the energy retaken from the grid depends strongly on the energy self-consumption of the household. It should be emphasized that the lower direct usage of energy causes a lower amount of energy retaken in the final balance calculated on the basis of the 'Prosument' system. According to the results, the highest amount of energy retaken equals $1874.6 \mathrm{kWh} / \mathrm{y}$ for azimuth $0^{\circ}$, whilst the lower value equals $1650.5 \mathrm{kWh} / \mathrm{y}$ (azimuth $60^{\circ}$ ). Reimbursement time is dependent on power capacity and the cost of the PV installation as well as on sum of the direct usage of energy and energy retaken from the grid. Reimbursement time varies from 10 to 11 years, independently on azimuth. 
Table 2. Estimated cost-reimbursement time of PV installation.

\begin{tabular}{|c|c|c|c|c|c|c|c|c|c|}
\hline Solar azimuth $\left[{ }^{\circ}\right]$ & -60 & -45 & -30 & -15 & $\mathbf{0}$ & 15 & 30 & 45 & 60 \\
\hline $\begin{array}{l}\text { Load consumption } \\
{[\mathrm{kWh} / \mathrm{y}]}\end{array}$ & \multicolumn{9}{|c|}{2550} \\
\hline Total energy cost $[€]$ & \multicolumn{9}{|c|}{346} \\
\hline Energy produced $[\mathrm{kWh} / \mathrm{y}]$ & 2711 & 2716 & 2905 & 2956 & 2972 & 2957 & 2903 & 2820 & 2703 \\
\hline Self-consumption [kWh] & 581.7 & 581.1 & 597.9 & 614.1 & 628.8 & 642.6 & 650.9 & 649.5 & 639.9 \\
\hline $\begin{array}{l}\text { Energy injected into the } \\
\text { grid }[\mathrm{kWh} / \mathrm{y}]\end{array}$ & 2129.3 & 2134.9 & 2307.1 & 2341.9 & 2343.2 & 2314.4 & 2252.1 & 2170.5 & 2063.2 \\
\hline $\begin{array}{l}\text { Energy retaken from the } \\
\text { grid [kWh/y] ('Prosument' } \\
\text { system) }\end{array}$ & 1703.5 & 1707.9 & 1845.7 & 1873.5 & 1874.6 & 1851.5 & 1801.7 & 1736.4 & 1650.5 \\
\hline Energy purchased $[\mathrm{kWh} / \mathrm{y}]$ & 264.9 & 261.0 & 106.4 & 62.4 & 46.6 & 55.9 & 97.4 & 164.1 & 259.6 \\
\hline $\begin{array}{l}\text { Cost of the purchased } \\
\text { energy }[€]\end{array}$ & 35.9 & 35.4 & 14.4 & 8.5 & 6.3 & 7.6 & 13.2 & 22.3 & 35.2 \\
\hline Reimbursement time [y] & 11.1 & 11.1 & 10.4 & 10.2 & 10.2 & 10.2 & 10.4 & 10.7 & 11.1 \\
\hline
\end{tabular}

Taking into account the price of energy purchased from the energy distributor, it can be assumed that the investment costs will return after 10 years. In order to obtain profits, the investment costs should be lower or modules should achieve higher conversion efficiency.

\subsection{Ecological analysis}

Fossil-fuel based electricity generation has harmful effects on the environment. In order to reduce the impact of fossil fuels usage on climate changes and to obtain sustainable development, conventional energy sources should be substituted by renewable sources. The benefits of renewable energy sources, such as solar energy are well known. It can be assumed that the reduction of carbon dioxide $\left(\mathrm{CO}_{2}\right)$ emission as well as other greenhouse gases, energy security and energy affordability are their main advantages.

In order to determine the influence of solar energy on reduction of greenhouse gases emission into the atmosphere the methodology proposed by National Center for Emissions Balancing and Management in Poland was used. Gaseous pollutants include chemical compounds such as dust, carbon monoxide $(\mathrm{CO})$, carbon dioxide $\left(\mathrm{CO}_{2}\right)$, sulfur dioxide $\left(\mathrm{SO}_{2}\right)$ and nitrogen compounds $\left(\mathrm{NO}_{\mathrm{x}}\right)$ were investigated. On the basis of the total electricity production and greenhouse gases emission in Poland, emissivity ratios were estimated, as follows $\mathrm{CO}_{2}-781 \mathrm{~kg} / \mathrm{MWh}, \mathrm{SO}_{2}-0.818 \mathrm{~kg} / \mathrm{MWh}, \mathrm{NO}_{\mathrm{x}}-0.824 \mathrm{~kg} / \mathrm{MWh}, \mathrm{CO}-252 \mathrm{~kg} / \mathrm{MWh}$, dust $-0.053 \mathrm{~kg} / \mathrm{MWh}[21]$.

Amount of the gases emission reduction obtained for PV installation of $2.9 \mathrm{kWp}$ size was presented in Table 3. Producing the same amount of energy requires combustion of $1338 \mathrm{~kg}$ of coal.

Table 3. Emission reduction of greenhouse gases.

\begin{tabular}{|c|c|c|c|c|c|c|}
\hline \multirow{2}{*}{$\begin{array}{c}\text { Installation } \\
\text { capacity }\end{array}$} & \multirow{2}{*}{$\begin{array}{c}\text { Energy } \\
\text { produced }\end{array}$} & \multicolumn{5}{|c|}{ Pollutants } \\
\cline { 3 - 7 } & & $\mathbf{C O}_{\mathbf{2}}$ & $\mathbf{S O}_{\mathbf{2}}$ & NOx & $\mathbf{C O}$ & Dust \\
\hline$[\mathrm{kWp}]$ & {$[\mathrm{kWh} / \mathrm{y}]$} & {$[\mathrm{kg}]$} & {$[\mathrm{kg}]$} & {$[\mathrm{kg}]$} & {$[\mathrm{kg}]$} & {$[\mathrm{kg}]$} \\
\hline 2.9 & 2972 & 2321 & 2.51 & 2.53 & 0.77 & 0.16 \\
\hline
\end{tabular}




\section{Conclusion}

In this paper self-consumption and total energy yield of photovoltaic installation dependency on solar azimuth modification were evaluated. Results of computational simulations show that the optimum solar azimuth for PV array located in Warsaw, capital of Poland, is $0^{\circ}$. Nevertheless, changes of the solar azimuth of the PV modules even to $60^{\circ}$ cause relatively small changes in final output power and thus in energy yield. In terms on self-consumption more effective orientations are towards the west, whilst those shifted to the East cause decreasing the direct usage of energy. An average value of $80 \%$ of total output power is unused directly and it is injected into grid. However, in terms on Polish legislation system ('Prosument'), the factor determining the cost-effectiveness of the PV installation is the sum of the direct usage of energy and energy retaken from the grid. Solar azimuth of location should be chosen properly to maximize these two indicators, which determine the reimbursement time. Taking into account the obtained simulation results, it should be emphasized, that for the solar azimuth that varies from $-60^{\circ}$ to $60^{\circ}$ the payback time is about 10 years. Production of $2972 \mathrm{kWh}$ energy from renewable energy sources cause reduction greenhouse gases emission, such as $\mathrm{CO}_{2}-2.3$ tons, $\mathrm{SO}_{2}-2.51 \mathrm{~kg}$, $\mathrm{NO}_{\mathrm{x}}-2.53 \mathrm{~kg}, \mathrm{CO}-0.77 \mathrm{~kg}$ and dust $-0.16 \mathrm{~kg}$.

\section{References}

1. M. Järvelä, S. Valkealahti, Appl. Sci. 7, 749 (2017)

2. L.-q. Liu, Z.-x. Wang, H.-q. Zhang, Y.-c. Xue, Renew Sust Energ Rev 14, 301-311 (2010)

3. A. Jager-Waldau, Renew Sust Energ Rev 11, 1414-1437 (2007)

4. D. Głuchy, D. Kurz, G. Trzmiel, Prz. Elektrotechniczny 89/6, 281-283 (2013)

5. F.J. Gómez-Gil, X. Wang, A. Barnett, Renew Sust Energ Rev 16, 306-313 (2012)

6. N. Krishna Kumar, V. Subramaniam, E. Murugan, Mater Today 5, 1076-1081 (2018)

7. M.A. Green, Y. Hishikawa, W. Warta, E.D. Dunlop, D.H. Levi, J. Hohl-Ebinger, A.W.H.Ho-Baillie, Prog. Photovoltaics Res. Appl. 25, 668-676 (2017)

8. P. Jackson, R. Wuerz. D. Hariskos, E. Lotter, W. Witte, M. Powalla, Phys. Status Solidi RRL 10, 583-586 (2016)

9. S. Gułkowski, E. Krawczak, E3S Web of Conferences 19, 03006 (2017)

10. A. Zdyb, E. Krawczak, P. Lichograj, Opt Appl 46, 181-185 (2016)

11. M. Lave, J. Kleissl, Renew Energy 36, 1145-1152 (2011)

12. L. Hirth, Energy Econ 38, 218-236 (2013)

13. J.M. Olchowik, S. Gułkowski, K.J. Cieślak, J. Banaś, I. Jóźwik, D. Szymczuk, K. Zabielski, J. Mucha, M. Zdrojewska, J. Adamczyk, R. Tomaszewski, Materials Science-Poland 24, 1127-1132 (2006)

14. S. Ghazi, K. Ip, Renew Energy 69, 50-59 (2014)

15. A. Zdyb, E.Krawczak, Environmental Engineering V, 261-266 (2017)

16. C.-Y. Lee, P.-C. Chou, C.-M. Chiang, C.-F. Lin, Sensors 9, 3875-3890 (2009)

17. Í. Portolan dos Santos, R. Rüther, RenewEnergy 63, 116-124 (2014)

18. K. Bakirci, Renew Sust Energ Rev 16, 6149-6159 (2012)

19. M. Hartner A. Ortner, A. Hiesl, R. Haas, Applied Energy 160, 94-107 (2015)

20. A. Gharakhani Siraki, P. Pillay, Sol Energy 86, 1920-1928 (2012)

21. Report: 'Wskaźniki emisyjności $\mathrm{CO}_{2}, \mathrm{SO}_{2}, \mathrm{NO}_{\mathrm{x}}, \mathrm{CO}$ i pyłu całkowitego dla energii elektrycznej na podstawie informacji zawartych w Krajowej bazie o emisjach gazów cieplarnianych i innych substancji za 2016 rok', Krajowy Ośrodek Bilansowania i Zarządzania Emisjami KOBiZE (2017) - in Polish language 